\title{
Revitalizing tourism in small regional towns through folklore-driven slow tourism: The example of Matyó land, Hungary
}

\section{Revitalizar a atividade turística em pequenas localidades através do turismo folclórico slow: 0 caso de Matyó, na Hungria}

\author{
Brigitta Pecsek \\ Enyedi György Doctoral School of Regional Sciences, Szent Istvan University, Hungary \\ brigitta.pecsek@gmail.com
}

\begin{abstract}
This paper raises the issue of revitalization of small town tourism through the lenses of folklore-driven slow tourism. Folk art is slow by nature; it promotes traditional craftsmanship, human creativity, hostlocal relations and community cohesion. Therefore, it has similar characteristics to the slow movement, particularly 'slow tourism'. In this paper 132 tourists were surveyed at the heart of the Matyó land, in Mezőkövesd, about the slow aspects of their holiday, their folklore consumption and their satisfaction with visit. The findings revealed: (1) visitors have some awareness of the slow movements; (2) respondents readily chose slower transport options; (3) A certain link could be established between more intensive consumption of folklore products and longer stay; (4) Visitors had a high satisfaction rate regarding the consumption of folklore products. Based on the results the author draws the conclusion that boosting the consumption of folklore products in the context of 'slow tourism' might be one way of revitalizing tourism in small regional towns.
\end{abstract}

Keywords: slow tourism; cittáslow; folklore; intangible cultural heritage; Matyó; Mezőkövesd.

\section{Resumo}

\begin{abstract}
Este artigo analisa o tema da revitalização de pequenas localidades através do turismo slow folclórico. A arte popular é lenta por natureza: promove o artesanato tradicional, a criatividade, as relações turista-anfitrião e a coesão da comunidade. Como tal, partilha características com o movimento slow, concretamente, com o slow tourism. Neste trabalho, 132 turistas foram inquiridos na localidade de Matyó, na Mezőkövesd, de modo a conhecer o lado slow das suas férias, o consumo dos produtos de folclore e o grau de satisfação com a visita. Os resultados revelam que (1) os visitantes têm conhecimento da existência dos movimentos slow, (2) os inquiridos prontamente escolhem opções de transporte mais slow, (3) há uma ligação entre o consumo mais elevado de produtos folclóricos e uma estada mais longa, e (4) os visitantes ficam muito satisfeitos com o consumo de produtos de folclore. Com base nos resultados, o autor conclui que, no contexto do slow tourism, o aumento do consumo de produtos de folclore pode ser uma forma de revitalizar o turismo em pequenas localidades.
\end{abstract}

Palavras-chave: slow tourism; cittáslow; folclore; património cultural intangível; Matyó; Mezőkövesd.

Dos Algarves: A Multidisciplinary e-Journal, 27 - 2016.

Special Issue Slow Tourism

ISBN 2182-5580 @ ESGHT-University of the Algarve, Portugal.

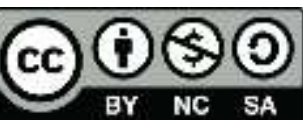

To cite this article: Pecsek, B. (2016). Revitalizing tourism in small regional towns through folklore-driven slow tourism: The example of Matyó land, Hungary. Dos Algarves: A Multidisciplinary e-Journal, 27, 94-119. doi: 10.18089/DAMeJ.2016.27.6 


\section{Introduction}

This article takes the case of small towns, and tries to put them onto the map of contemporary tourism. In this endeavour it will be argued that culture, notably folklore traditions tied to slow tourism, can serve as an efficient tourism marketing tool. In the literature review the problems small towns face are discussed, followed by an overview of the 'slow' philosophy as a counterculture born in reaction to the superfast-paced modern world. Although slow tourism has been a mainstream staple for some time now providing a truly diverse collection of academic work (e.g. Caffyn, 2012; Dickinson, Robbins and Lumsdon, 2010; Dickinson and Lumsdon, 2010; Fullagar, Markwell and Wilson 2012; Honoré, 2005; Lumsdon and McGrath 2011; Murayama and Parker, 2012; Parkins, 2004; Sugiyama and Nobuoka, 2007; Uchida, 2006), the interlink between slow and other tourism types is under-theorized, so the intersection of slow and folklore is also yet to be reviewed.

The literature review is followed by the author's own folklore-led tourism model and the analysis of the empirical research set in Mezőkövesd, a small town at the heart of the Matyó land. The research revolves around the following key themes: first, it seeks to examine respondents' slow aspects of their holiday including transport choice to and at the destination, and the length of stay of their holiday. Next, their awareness of 'slow' is analysed, followed by the examination of folklore products consumption, and the analysis ends by looking into the satisfaction level of cultural tourists versus spa tourists.

The concluding remarks point out several issues waiting to be resolved. The author argues that Mezőkövesd has some important ingredients that can be packaged as a slow destination and with the fusion of folklore and slow, the successful repositioning of Matyó culture can take place. As a result, visitors might have additional incentives to stay longer at the destination. In the paper the term 'culture' and 'folklore' are used interchangeably, as the culture of Mezőkövesd is solely based on the Matyó folklore. 


\section{Literature Review}

\subsection{Small towns, big problems}

The definition of small and medium towns is a fluid category. Jamieson (1993) defines small and medium sized towns (SMSTs) as having between 5,000 and 50,000 inhabitants. In his paper, he writes about the major challenges small towns are facing such as economic decline owing to ageing societies, depopulation, depleting tax base, businesses moving away, low community spirit, and ailing agriculture. At the same time, he points towards cultural tourism as a way forward. American terminology contrasts metropolitan with micropolitan, and according to the US Census Bureau (2015) the latter "is a micro area containing an urban core of at least 10,000 (but less than 50,000 ) population". In Hungary the classification shows great variations, although Pirisi (2008), who carried out extensive research into Hungarian small towns, used the range 5,00030,000 in terms of population.

The plight of smaller settlements is at the heart of several European initiatives. ECOVAST is the European Council for the Village and Small Town set up in 1984 to further the wellbeing of rural communities, and safeguarding the rural heritage. Within this framework the most notable initiative so far is 'Action to Strengthen Small European Towns' (ASSET), which has managed several pan-European Studies. According to their latest figures nearly 78 million Europeans live in 4,580 small towns with a population of 10,000-30,000. In addition, towns between 30,000 and 50,000 are still considered 'small' and 1,210 were identified with a combined population of more than $45,000,000$. The organization emphasizes the positive contributions of small towns to landscape and people's wellbeing, constituting an important part of the hierarchy of European settlements (European Council for the Village and Small Town [Ecovast], 2010).

Another European scheme recognizing the complexity of small towns' problems is called Urban Vision Central Europe Small Town 2020 (European Union - European Regional Development Fund, 2013). However, it deals with some of the issues raised in a conventional way, for example, the ageing population becomes merely a transport and health issue and it does not offer any solutions as to how to turn around current demographic decline or how to bring creative energies into towns. 
The United States Census Bureau (2015) confirms that spatial inequality has been growing for decades. Dure (2014) points to the fact that younger generations are flocking to expensive urban centres, and affordable housing does not play a role in their decision. Instead, economic opportunity is the key and small communities are currently failing in that respect. Some viable solutions are discussed in a book entitled Small Towns, Big Ideas: Case Studies in Small Town Community Economic Development (Lambe, 2008) compiled by the University of North Carolina, describing a collection of 45 inspirational examples. One of the key findings of those case studies is that "defining assets and opportunities broadly can yield innovative strategies that capitalize on a community's competitive advantage" (Lambe, 2008: 6). Elkin, a small town in North Carolina, decided to build on the local craft economy and invested in a craft guild and an apprenticeship program that provides crafts training, mentorship and small business courses to artist entrepreneurs. This is a shining example of how the craft industry tied to tourism promotion might be a potential economic engine.

In addition to economic failure, not a negligible number of them face serious branding problems as Bill Baker (2007) in his seminal book Destination Branding for Small Cities concludes. He claims that many small towns lack a unique selling proposition (USP); consequently, they are much less attractive for both tourists and settlers than bigger ones. In contrast, big cities are flourishing as preferred places of residence as well as tourism destinations. They are also boosted by low airfares and the convenience of online booking available for individual travellers. As for small towns becoming slow cities and/or turning to slow tourism, this might be a road to survival and to eventual prosperity. Small towns' charms lie partly in their community and slow tourism is a tool to showcase that community spirit through local food and culture. Tietz and Rothhaar (1991) list the following areas to be addressed in strategic planning for small towns:

- Enhance green spaces and sports opportunities

- Create communications spaces like passages

- Improve the centre through construction, restoration and heritage protection

- Strengthen the market function of the town by organizing flea, food and crafts markets

- Support events to improve image 


\subsection{Cittaslow and slow tourism}

The Cittaslow (slow cities) movement emerged in 1999 to counterbalance the unchallenged urbanization and superfast-paced life. It was built upon the first grassroots initiative - slow food - launched in 1984 by the Italian Carlo Petrini in Pollenzo to protest against the opening of a McDonald's restaurant in Rome (Slow Food, 2015). In 2014, the number of slow cities reached 192, but to date only one Hungarian town, Hódmezővásárhely, has qualified. This initiative gives an alternative for those who enjoy the perks of cities (heritage and culture) without the speed and pollution. Although the beneficiaries of its main principles such as environment preservation, resident-friendly infrastructure, reuse and recycling, and great hospitality are primarily local residents, urban areas of smaller scale (with a population of less than 50,000 ) create fertile grounds for slow tourism, as a growing number of travellers find the promise of the slower pace attractive (Cittaslow, 2014).

Mayer and Knox (2006) demonstrated in their case studies through the examples of two German towns - Waldkirch and Hersbruck - how embracing Cittaslow values can work in terms of urban development. Another more recent, well-documented case is Tarakli, Turkey, where scholars (Adigüzel and Erikci, 2013) describe the process of becoming a slow city. Korkmaz, Mercan and Atay (2014) successfully link branding with the Cittaslow philosophy through the example of Seferihisar, Turkey.

One key strand of literature on slow tourism is connected to Dickinson and her colleagues, who developed a widely accepted concept of slow travel: "Slow travel is an emerging conceptual framework which offers an alternative to air and car travel, where people travel to destinations more slowly overland, stay longer and travel less" (Dickinson et al., 2010: 1).

They emphasise that the way of travelling is an integral part of the trip and that only slow means of transport are acceptable. Likewise, Lumsdon and McGrath (2011) outlined four core principles: slow mobility, locality, means of transport and environmental protection. They stress that slow transport and slow activities deepen the tourist experience. 
Outside Europe, contemporary social scientists in Japan have also taken the issue of the fast and slow dichotomy. Japan is the quintessence of binarity, where hyperfastness exists in tandem with the super slow traditions such as tea ceremonies or onsen (hot springs) rituals. Sugiyama and Nobuoka (2007) delivered their own slow tourism concept, which is on the one hand less restrictive than the concept above, as car usage is allowed; and on the other hand, it is more holistic by placing greater focus on selfrealization, health and active lifestyle. Their whole slow concept is a wide umbrella term (Murayama and Parker, 2012) including different types of alternative tourism such as green tourism, ecotourism and agri-tourism.

Another lens is Caffyn's (2012), who embraces the hedonistic side of slow tourism, which might make it easier to promote slow tourism to a wider spectrum of travellers. Consequently, her idea of slow is not about the drastic reduction of consumption, but opting for slower local choices in terms of eating, drinking and shopping. As regards longhaul travel, she suggests that the ratio of distance travelled and the time spent at destination is a more meaningful and realistic measurement. She also argues that some remote destinations are in desperate need of tourism revenues and the exclusion of air travel might put poor, faraway destinations at a disadvantage. Her concept of slow echoes Honoré's (2005) and Petrini's (2007) interpretation of slow, which also highlights the enjoyment of good food, good drink and good company at the right tempo.

There is a striking lack of research from the Central-Eastern European perspective, which needs to be addressed. First of all, speed is a culturally-loaded term and it has a much more positive connotation in the post-socialist countries, for example, fast cars and regular European city breaks indicate high economic and social status. There is no Hungarian equivalent of the term 'downsizing' and slow tourism has not entered into the realm of academic discussion either. Without a strong rural tourism base, but with a long tradition of bathing culture and rituals as well as some idiosyncratic cultural traditions, it is highly likely that the eventual concept will take a more holistic turn adopting some aspects of the Japanese concept. In fact, comparative studies have already been carried out by Rátz (2010) on bathing. It is also more than probable that it will heavily rely on the Cittaslow principles as the most active civil initiatives are all connected to urban areas. Slow maps of Budapest (Slow Budapest, 2015) and Szeged 
have already been designed and regular events such as thematic days, talks and walks are regularly held in both cities.

While dissecting the existing definitions of slow tourism, the negligence of the economic aspect is palpable, without which a slow concept has less chance in the Hungarian context. If local communities do not see concrete economic benefits, any discussions about slow in any shape or form will be nothing but a failed theoretical effort. This is the rationale behind the focus of this paper; notably more emphasis has been placed on the potential directions of a solid 'slow' marketing strategy based on folklore rather than on the contribution to the development of a global concept.

\title{
2.3 The concept of heritage and folklore
}

Heritage means "[v]alued objects and qualities such as historic buildings and cultural traditions that have been passed down from previous generations" (Online Oxford Dictionaries, 2014). Our main concern here is folklore, which is part of intangible cultural heritage. According to the 2003 Convention for the Safeguarding of the Intangible Cultural Heritage, intangible cultural heritage $(\mathrm{ICH})$ is defined as follows:

\begin{abstract}
Intangible Cultural Heritage means the practices, representations, expressions, knowledge, skills - as well as the instruments, objects, artefacts and cultural spaces associated therewith - that communities, groups and, in some cases, individuals recognize as part of their cultural heritage. This intangible cultural heritage, transmitted from generation to generation, is constantly recreated by communities and groups in response to their environment, their interaction with nature and their history, and provides them with a sense of identity and continuity, thus promoting respect for cultural diversity and human creativity. (United Nations Educational, Scientific and Cultural Organization [UNESCO], 2003: 2)
\end{abstract}

According to the American Folklore Society (AFSNET, s.d.: 1):

Folklore is the traditional art, literature, knowledge, and practice that is disseminated largely through oral communication and behavioural example. Every group with a sense of its own identity shares distinct folk traditions ranging from planting practices to family traditions, has a certain way of doing things like dancing, making music or sewing clothing, knows how to build and make architecture, art and craft, and say personal experience stories, riddles or song lyrics.

The concept of folklore has invited several thinkers to formulate their definitions. Noyes (2004: 375) focuses on the aspects of being 'not modern': “Folklore is a 
metacultural category used to mark certain genres and practices within modern societies as being not modern." Why study folklore? The most comprehensive summation is given by Wilson (1988: 156) who stresses that no other discipline is more concerned with linking us to our cultural heritage from the past. Moreover, it shows the interrelationships among different cultural expressions and reveals the basis of our common humanity.

For the purpose of this study, folk arts and crafts are included in the concept of folklore as in the AFSNET definition above, since Matyó heritage relies heavily on traditional arts and crafts (clothing, embroidery, jewellery, pottery and furniture) which are interlinked with performing and oral traditions such as wedding ceremonies, festivals, dancing and singing.

Folklore with its small scale and imperfections constitutes a sharp contrast to the sanitized global world. Therefore, strong folkloristic traditions can give a competitive edge to a particular area, which is certainly a blessing for any emerging or struggling tourism destination. Folklore is mostly experienced in the countryside, which has been neglected in terms of tourism development in several countries. The reason being is that creative energies today are associated with fast-paced bustling megapolises. This article refutes this argument by saying that folklore is creative and since creativity requires time and effort, it is also slow by nature, and therefore can be rightfully placed in the slow tourism concept.

The Hungarian Elements on the UNESCO List of Intangible Cultural Heritage (UNESCO, 2009, 2011 and 2012: 1) include:

1. The dancehall or Táncház method: a Hungarian model for the transmission of intangible cultural heritage.

2. Busó festivities at Mohács: masked end-of-winter carnival costume.

3. Falconry, a human living heritage.

4. Folk art of the Matyó - embroidery of a traditional community. Motifs decorate traditional dresses worn by local people in celebratory events, in folk dancing and singing performances. Matyó motifs are also featured in furniture, arts and crafts. 
B. Pecsek

\section{Where slow meets folklore}

Figure 1: The model of folklore-driven slow tourism

Factors

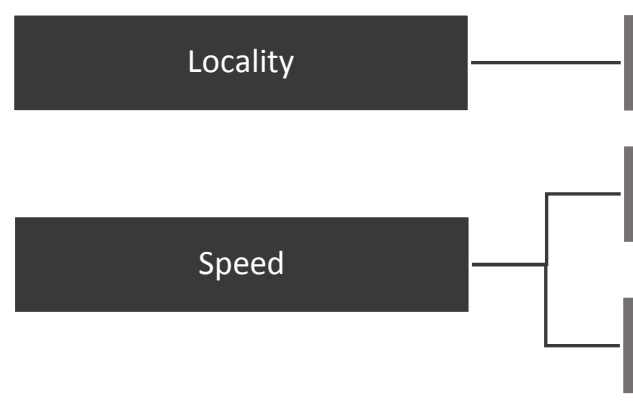

Community
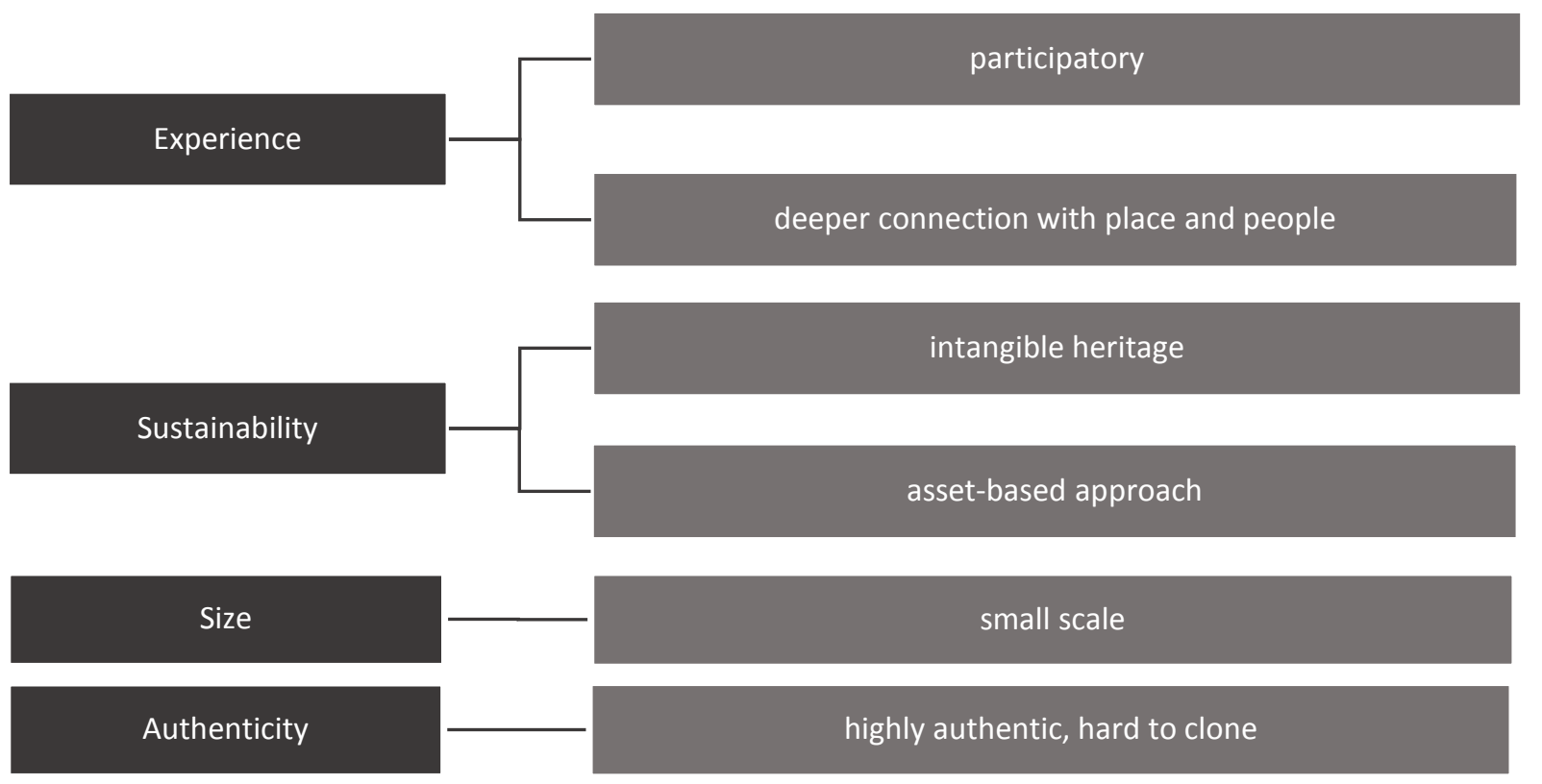

Quality

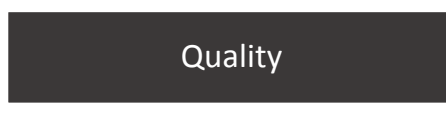

Means of production

Technique

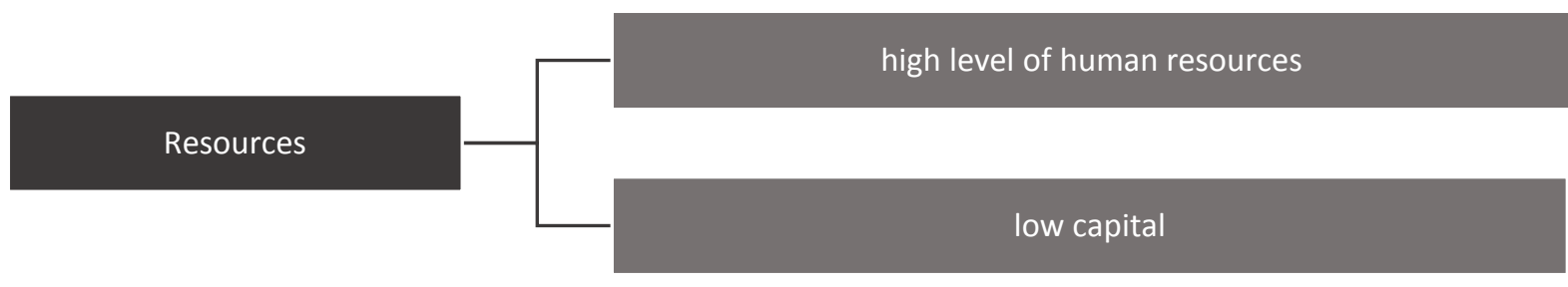

Source: Author.

\section{Elements}

place attachment

slow production

slow consumption

community-driven

small scale

highly authentic, hard to clone

some irregularity due to handcrafted character

hand-made

traditional (handed down through generations) 
The preservation of intangible heritage is more complex and requires a knowledgeintensive approach as its success greatly depends on the people who naturally become the custodians of this heritage by practising and passing on its legacy. Unfortunately, traditions are often poorly documented; as a result, intangible cultural heritage is very fragile and vulnerable (Mallik, Chaudhury and Ghosh, 2011).

To illustrate folklore-driven slow tourism visually, a graphic representation is shown in Figure 1. In the model eleven relevant factors were used, with one or two elements attached to them. One set is featured in most literature on slow tourism, and others are my own ideas conceived while experiencing folklore first-hand. The former include: locality, speed, community, experience, sustainability, size and authenticity (Caffyn, 2012; Dickinson et al., 2010; Dickinson and Lumsdon, 2010; Fullagar et al., 2012; Honoré, 2005; Lumsdon and McGrath 2011; Murayama and Parker, 2012; Sugiyama and Nobuoka, 2007; Petrini, 2007). The aspects of means of production, technique and quality are related to folklore and reflect the characteristics of the hand-made arts and crafts. The factor of resources was also added to emphasize that folklore-driven slow tourism is more labour-intensive than other forms of tourism. This is far from an exhaustive inventory of factors; however, with some alteration it is possible to apply the model for linking slow tourism to other forms of tourism.

\section{Mezőkövesd: location, tourism and culture}

Mezőkövesd is situated in the North-Hungarian region, in Borsod-Abaúj-Zemplén (BAZ) County. It lies $130 \mathrm{~km}$ from Budapest, $60 \mathrm{~km}$ from Miskolc (regional centre) and $20 \mathrm{~km}$ from Eger (local centre). The town is reached by M3 highway, with the closest international border checkpoint (to Slovakia) being Bánréve (70 km). The furthest is Letenye (to Croatia), around $370 \mathrm{~km}$ away, while the Austrian border is $300 \mathrm{~km}$ distant.

I selected Mezökövesd as the centre of my research because the town suffers from most of the problems that many small towns in Hungary and indeed worldwide face today. Its dwindling population currently stands at 16,502 and has been declining gradually for over a decade (Hungarian Central Statistical Office, 2015). Between 2000 and 2014 it lost $8 \%$ of its residents due to two main factors: low birth rate and outward migration of the young, better-educated generation. Depopulation is a highly 
disadvantageous situation in terms of sustainable tourism development since the sustainability itself will be in danger due to the shortage of a qualified workforce and local enthusiasts who would volunteer, promote and present their tourism attractions to visitors. The town lies in a disadvantaged county of Hungary which has missed the boat of attracting corporate investment that would boost creative energies, and locals have no financial means to set up enterprises, so unemployment is rampant.

On the bright side, Mezőkövesd is rich in 'soft assets', being famous for its spa culture as well as its UNESCO listed Matyó heritage. In 1938 a thermal spring was found and later a thermal bath was built. This part of the town has evolved into a true health resort with a wide selection of accommodation to cater for all pockets. Hungary has an internationally acclaimed and highly competitive spa and wellness culture and health resorts are among the honey-pots for international and domestic visitors alike. Unfortunately, Mezőkövesd is under-performing in this regard, so the challenge is to turn the town into a high performing destination. One possible way to achieve this is to make its unique cultural traditions more visible through marketing it as a slow destination.

Table 1: Comparative data: Tourism in selected health resorts in Hungary, 2014

\begin{tabular}{lccccc} 
Towns & $\begin{array}{c}\text { Number of } \\
\text { visitors }\end{array}$ & $\begin{array}{c}\text { Number of guest } \\
\text { nights }\end{array}$ & $\begin{array}{c}\text { Average length of } \\
\text { stay [nights] }\end{array}$ & Population & $\begin{array}{c}\text { Ratio visitors/ } \\
\text { resident }\end{array}$ \\
Hévíz & 187,530 & 987,367 & 5.3 & 4,634 & 40.47 \\
Hajdúszoboszló & 228,922 & 803,671 & 3.5 & 23,882 & 9.59 \\
Bük & 166,223 & 679,835 & 4.1 & 3,256 & 51.05 \\
Sárvár & 165,863 & 452,496 & 2.7 & 15,651 & 10.60 \\
Zalakaros & 128,250 & 428,900 & 3.3 & 1,791 & 71.61 \\
\hline Mezókövesd & 38,337 & 105,706 & 2.8 & 16,502 & 2.32
\end{tabular}

Source: Hungarian Central Statistical Office, 2014.

Table 1 clearly illustrates how far Mezőkövesd lags behind the most popular health resorts in Hungary. Both the number of visitors and the guest nights in Mezőkövesd pale in comparison with the results of the other settlements. The average length of stay is the second lowest among the examined resorts and almost half that of Héviz. Analysing the ratio of the number of visitors in relation to residents, the picture 
is even bleaker. It is obvious that relying exclusively on spa tourism in terms of boosting tourism revenue is not working in the case of Mezőkövesd.

Figure 2: Accessibility of Mezőkövesd

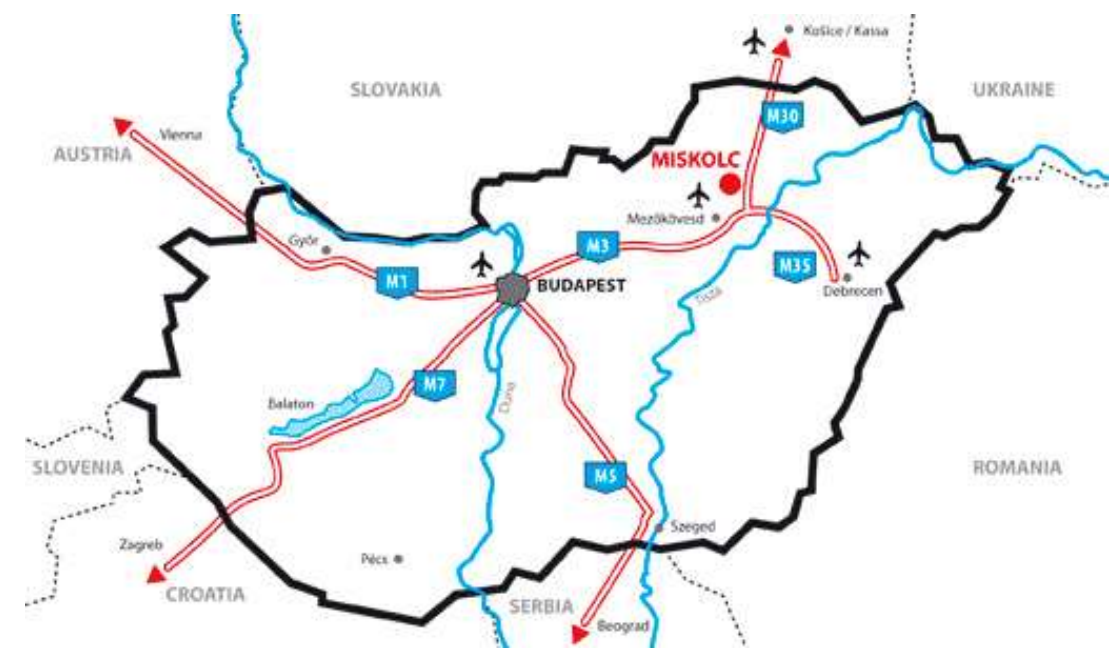

Source: www.mechapark.hu/en/mechatronics-industrial-park, 2014.

In terms of accessibility Mezőkövesd has great potential as it is easily reachable from all corners of the country (Figure 2) by a great variety of transport modes, including slower options such as train or coach. The Budapest-Miskolc-Kosice Intercity goes through the town eleven times on an average day, linking it with the capital city and the north of Hungary. The railway station is $1.5 \mathrm{~km}$ from the town centre and it takes about 1 hour 50 minutes to reach the town from Budapest. The coach station is merely $500 \mathrm{~m}$ from the centre and coaches reach the capital within 1 hour 45 minutes. There are no navigable waterways through the town; the closest, the River Tisza being 25 kilometres away. The closest international airports include Budapest - Liszt Ferenc airport (150km), a low-cost airport in Debrecen $(110 \mathrm{~km})$ and the Slovakian airport in Kosice (135 km). Within the town, a regular bus service, cycling and walking are all viable options; the length of the dedicated cycling track is over $6 \mathrm{~km}$.

The origin of the name "Matyó" ${ }^{1}$ is debated: it is thought to have been a common word around the early 19th century to designate a group who became Catholic, during

\footnotetext{
${ }^{1}$ Legend has it that a Matyó man was once kidnapped by the devil. His lover begged the devil to let him free. The devil was willing to do this on one condition: "Bring me the most beautiful flowers of the summer in your apron and you can take your lover back." It was wintertime, so the girl embroidered the loveliest flowers on her apron and took it to the devil.
} 
the Counter-Reformation. There is also a belief strongly held in local folk tradition that the name is a distorted and familiar form of the name Mátyás due to the fact that market town privileges were given to the town by King Matthias (see www.matyovk.hu). The Matyó culture is one of the last strongholds of authentic cultural manifestations in Hungary. Tard and Szentistván, two neighbouring villages, also belong to the Matyó community; however, historically the Roman Catholic inhabitants of Mezőkövesd had a key role in the establishment of Matyó cultural identity, so my explorations are spatially limited to that community.

Unlike some other intangible heritage on the UNESCO World Heritage list, Matyó culture differs in a way that not only a particular performance or cultural manifestation is worth protecting but also everything that features Matyó embroidery. Therefore, there are multiple opportunities such as festivals, museums, arts and crafts to be engrossed in real Matyó experiences. Right in the town centre the former Korona (Crown) Hotel houses the Matyó Museum, which showcases a comprehensive introduction to the Matyó folk art and the everyday life of people living at that time. However, the most authentic representation is the Hadas district where a neighbourhood comprising twelve preserved peasant houses was turned into an openair museum and offers visitors close encounters with this unique folk art (Figure 3 and 4). The following exhibitions and workshops welcome visitors (mezokovesd.hu, 2014):

Figure 3: Hadas district

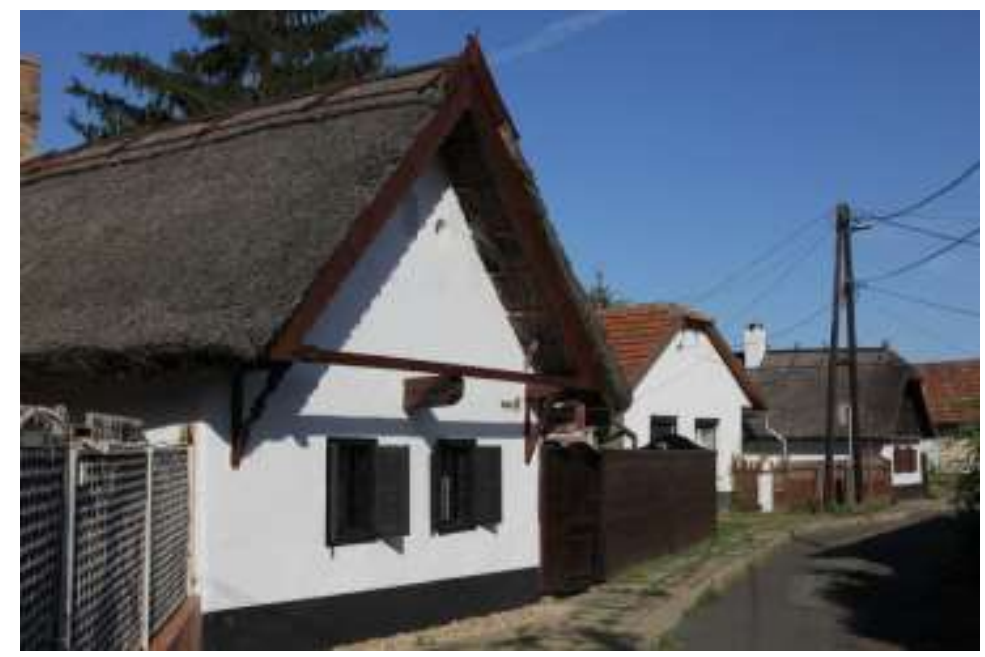

Source: Photo taken by the author (2014). 
- In the Gingerbread Village House of Anna Pető, visitors can learn about the gingerbread making and enjoy the permanent exhibition.

- The Furniture Painting Workshop shows the works of Szabolcs Kovács and the 250-year-old furniture painting traditions.

- In the Kisjankó Bori Memorial House visitors can learn about the life of the "drawing woman" of Mezőkövesd with the help of some original furniture.

- In the Toyhouse, the toys of former Matyó children as well as old weaving and spinning tools provide fascinating insights.

- A music house operates in the Gari Takács Margit Memorial House, which displays a wide range of folk instruments.

- The historic building that is used by painter, Mihály Laczkó Pető and graphic designer and hand weaver, Aranka Tábori as a creative house and exhibition space is a unique heritage from 1817.

- In the House of Enamels and Embroideries the adventurous can try the technique of hand embroidery.

- In the Pottery House, visitors can find everyday folk items and learn about pottery making.

Figure 4: Exhibition in the Hadas district

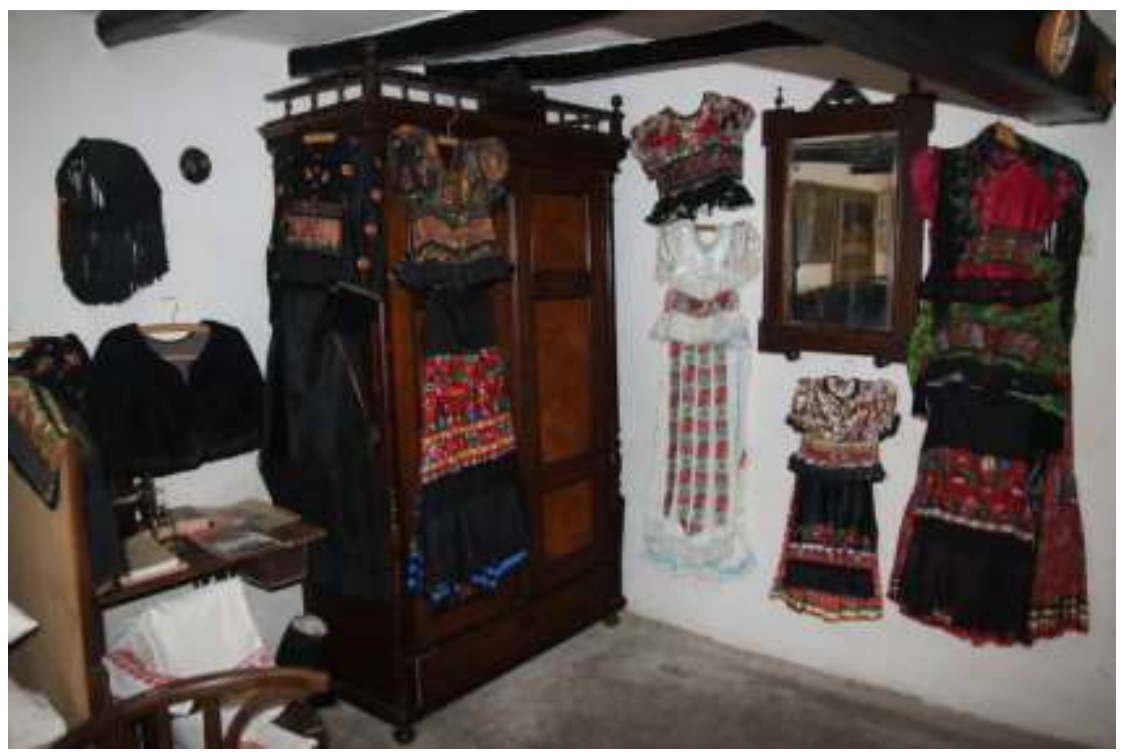

Source: Photo taken by the author, 2014. 
In 2014 eight programs related to Matyó folklore were held in Mezőkövesd spanning from January to September (Table 2). However, it is poor planning not to extend the official "Matyó festival season" until the end of the year. It would be advisable to fill already established traditional celebrations (St. Martin's Day, Advent) with some Matyó content, so that cultural visitors' needs could be met all year round.

Table 2: Cultural events related to Matyó culture in 2014

\begin{tabular}{ll} 
Date & Name of events \\
\hline 18 January & Fest of Matyó Rose \\
$20-21$ April & Matyó Easter \\
20 June-30 September & 100 Roses Embroidery Exhibition \\
21 June & Night of the Museums \\
$15-21$ July & First Matyó World Summit \\
$21-22$ July & Day of the Town - Matyó Festival \\
$1-3$ August & Matyó land folklore festival \\
$20-21$ September & Day of Cultural Heritage \\
\hline
\end{tabular}

\section{Sampling and Methods}

The survey was carried out over the autumn months of 2014, when 150 questionnaires were distributed and 132 valid responses were obtained. Convenience sampling was selected, but to avoid the pitfalls of collecting information only from one type of visitors, questionnaires were distributed in the Hadas district, the Tourinform Office and the Matyó Association Office, all located in the town centre, as well as in the neighbourhood of the thermal bath where most tourist accommodation is found. It should be noted that the health resort is located four kilometres from the town centre.

The research questions revolve around the following key themes. First, the survey seeks to examine respondents' slow aspects of their holiday including transport choice to and at the destination, and the length of stay of their holiday. Then their awareness of slow is analysed, followed by the examination of folklore products consumption. Finally, it looks into the satisfaction level of cultural tourists versus spa tourists. 
The following hypotheses were focused upon: 1 . Visitors have some awareness of the slow movements; 2 . Respondents readily chose slower transport options; 3 . There is a link between more intensive consumption of folklore products and a longer stay; 4. Visitors have a high satisfaction rate regarding the consumption of folklore products.

\section{Results and Discussion}

\subsection{Slow mobility}

Since slow mobility is such an integral part of slow tourism there is some merit in discussing it first. The question was related to the means of transport participants used. According to the findings $66 \%$ of respondents used their car to reach the destination and about one-third (34\%) opted for slower means of transportation including coach, rail or bicycle, which is quite encouraging. Unfortunately, most drivers (92\%) continued using their car within the destination and only a negligible number switched to slower options, mainly walking, which indicates that car travellers remain car travellers regardless of the distance they are supposed to cover.

When asked about their permanent residency, most respondents reside either in Pest County (27\%), or in BAZ County $(31 \%)$ and this fact is also favourable for the development of slow tourism, since residents in both counties have the most convenient access to the destination due to their proximity and the variety of transport choice. Out of the 19 Hungarian counties, five were not represented by respondents; all those counties are located far in the Western part of Hungary and possess unmatched spa and wellness facilities and services. As expected, Pest county residents used their car in greater number (70\%), while only $55 \%$ of in-county travellers did so.

The second topic to be explored was the length of stay. Dickinson and Lumsdon (2010: 38) suggest that the longer the time tourists spend at a destination, the slower they become, because their travel carbon foot print is spread over a longer stay. Unfortunately, 44\% did not spend any nights in Mezőkövesd and only one tenth stayed a week or more at the destination. Yet $56 \%$ met one of the prerequisites for slow tourists by staying at least a night as defined in the literature (Caffyn, 2012; Dickinson and Lumsdon, 2010; Sugiyama and Nobuoka, 2007). The fact that those tourists did not regard the town as a mere one-day destination could be an encouragement for local 
stakeholders to find ways of keeping one-night visitors longer at the site and transforming them into 'slower' tourists. Pest county residents stayed overnight in greater proportion (63\%), while $48 \%$ of in-county visitors did the same.

\subsection{Awareness of slow}

The next question was about the respondents' awareness of the main slow movements: "Have you heard any of the following slow movements: slow food, slow cities or slow tourism?" Respondents had to tick as many as they had heard of. The rationale behind this question was to help marketers finding the right approach to tourism strategies (see Figure 5).

Figure 5: Respondents' knowledge of slow movements

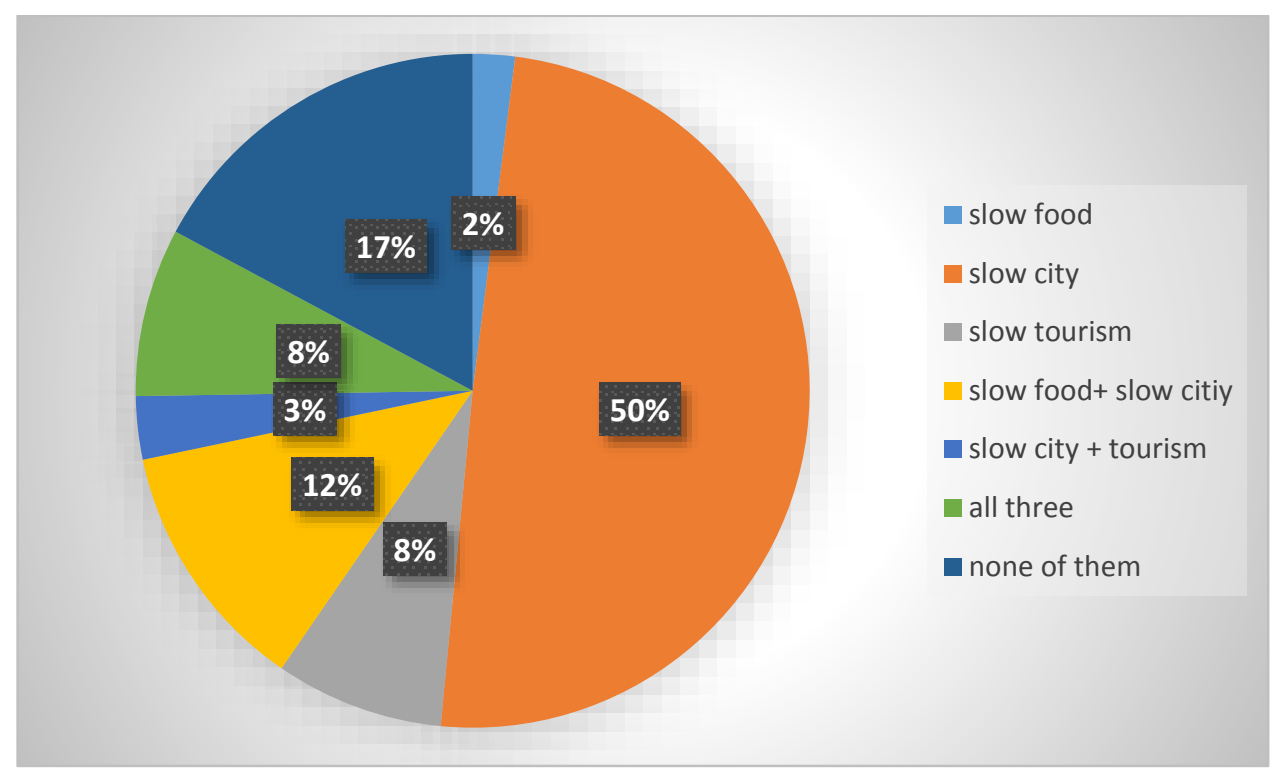

Source: Author.

It is promising that only $17 \%$ had no knowledge whatsoever of any of the movements, which suggests that in this media cacophony, the voices of slow life advocates are getting through and have already reached the great majority of respondents. Half of the respondents had heard about slow cities at the time of the survey, which might be due to the fact that the first Hungarian Cittaslow member, Hódmezővásárhely was heavily featured in the news at the time of their candidacy in 
2011 and whenever it recurs in the news, the slow city title always resurfaces in the rhetoric. Urban civil initiatives in connection with slowing down in an urban environment are regularly featured in the media. The issue has been embraced primarily by the young and hip urban generation; therefore, a wider layer of society is captured thanks to both the alternative media and the social media, as opposed to the slow food movement, which has stronger foothold in the countryside, and is often seen as the last resort to survive and protect gastronomic heritage. Members are joined in local chapters known as convivia (singular: convivium), simply meaning local groups. To date there are 1,300 convivia (Slowfood, 2015).

This approach is a far cry from the urban hip, so it is more difficult for them to seize the media opportunity and get the message through, which might be a reasonable explanation for this paltry $2 \%$ who had heard of slow food. The picture is brighter if we add those $12 \%$ who were aware of both slow city and slow food. A further $3 \%$ had some ideas about slow city and slow tourism. Interestingly, only $19 \%$ of participants heard about slow tourism in any combinations as opposed to $73 \%$ who heard about slow city. This means that it would be worthwhile to approach slow tourism through Cittaslow because the latter is a much better-known concept.

\subsection{Interest in Matyó culture}

Figure 6 shows visitors' main travel motivations, where leisure purpose was divided into two categories: cultural tourism and health tourism, the latter so far being the main drawcard of the area. However, the survey suggests that respondents were more interested in the Matyó culture, since nearly half of the participants mentioned cultural tourism as their main reason for travel, followed by health tourism, as roughly one-third went to Mezókövesd for that purpose. The number of those who were visiting friends and relatives was negligible and the business purpose was hardly measurable. Respondents contributed freely to the 'other' reason category, mentioning simple relaxation or hospitalization. The lack of business travellers is very unfortunate as this type of tourism always yields handsome revenue to a host destination. Unfortunately, there is no tradition of holding business meetings in spa hotels in Hungary. 
Figure 6: Travel motivation

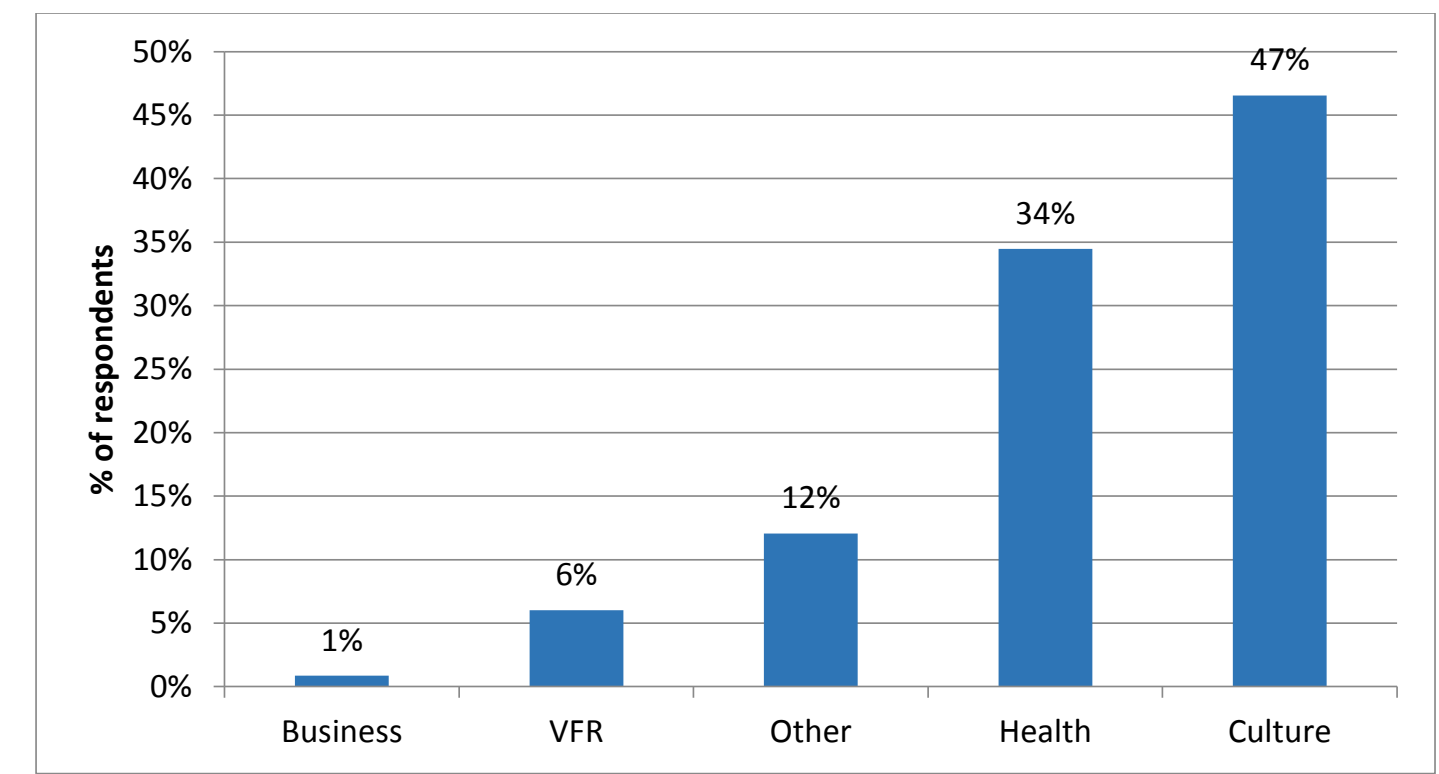

Source: Author.

The next issue raised was the participants' consumption of folklore products. Respondents were asked to select as many products as they visited from a list of 12 cultural items. Among them, eight are situated in the Hadas district (listed above), besides which the Matyó Museum, the Agricultural Museum and two churches were included in the list. Respondents visited four attractions on average and the Matyó Museum stood out as the most popular sight, visited by $82 \%$ of people, almost twice as many as the second most popular attractions including the two churches, the Agricultural Museum and Kisjankó Bori's Home. Those who stayed overnight in the town visited 5.6 sights on average. But even the excursionists managed to visit 3.5 sights on average, which is quite impressive given the short time-frame. Whether there is any chance to encourage day-trippers to stay any longer is another question.

What emerges from this examination is that the duration of the visit and the number of cultural sights appear to be interlinked. However, the real "culture vultures" were those who stayed four to six nights in Mezőkövesd, who visited seven cultural sights on average during their stay, substantially more than those who stayed over a week. 
Figure 7: Szent László Church

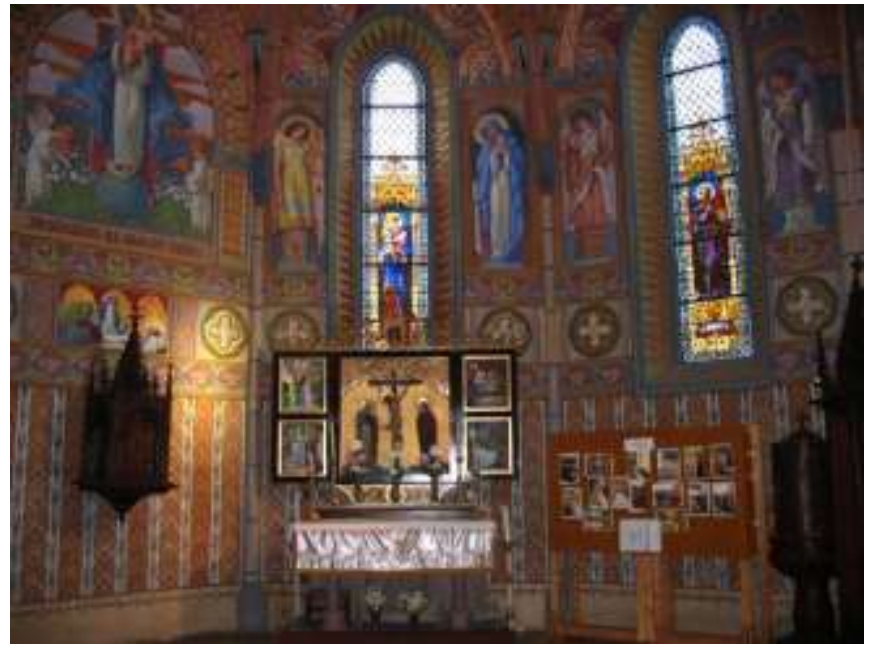

Source: Photo taken by the author, 2014.

The explanation may lie in the motivation for the trip, since the latter group came to Mezőkövesd either to enjoy the spa and wellness facilities and services available or to visit friends and relatives. As can be seen in the Figure 8 , the number of sights visited increases sharply up to the length of 4-6 nights where it peaks, and then drops dramatically to 2.3 attractions.

Figure 8: The number of nights spent versus the number of cultural sights visited

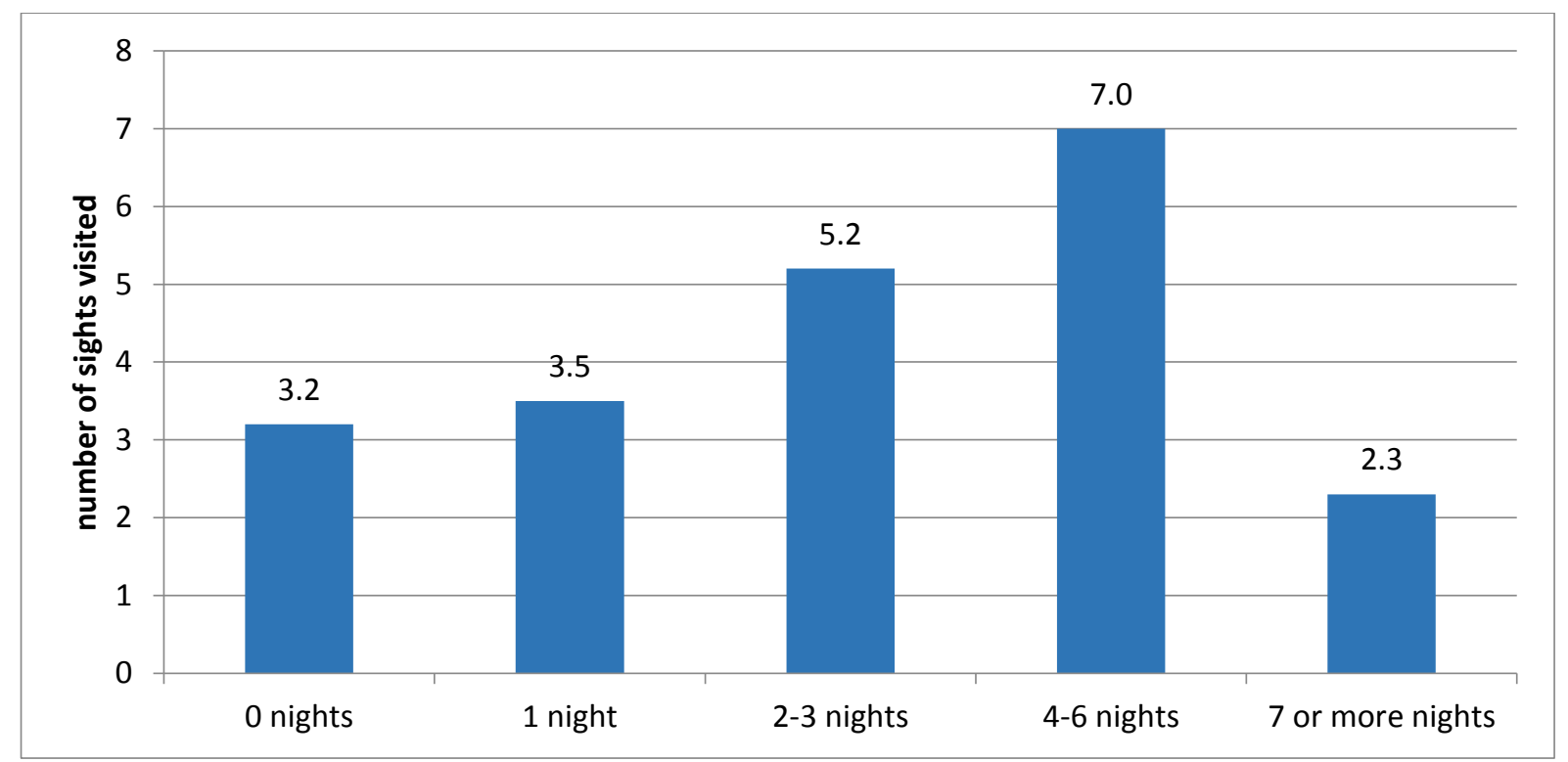

Source: Author. 


\subsection{Satisfaction with visit}

Fifty-three per cent of respondents were visiting Mezőkövesd for the first time, while $47 \%$ were returning visitors, so the data shows a high level of loyalty among tourists on which tourism planners and marketers can build. For the sake of this analysis, I grouped the respondents according to their motives to identify any difference between their satisfaction levels, should there be any. My initial assumption was that cultural attractions contribute to the positive experience visitors have in Mezőkövesd regardless of their prime motivation.

Figure 9: Degree of satisfaction with visit

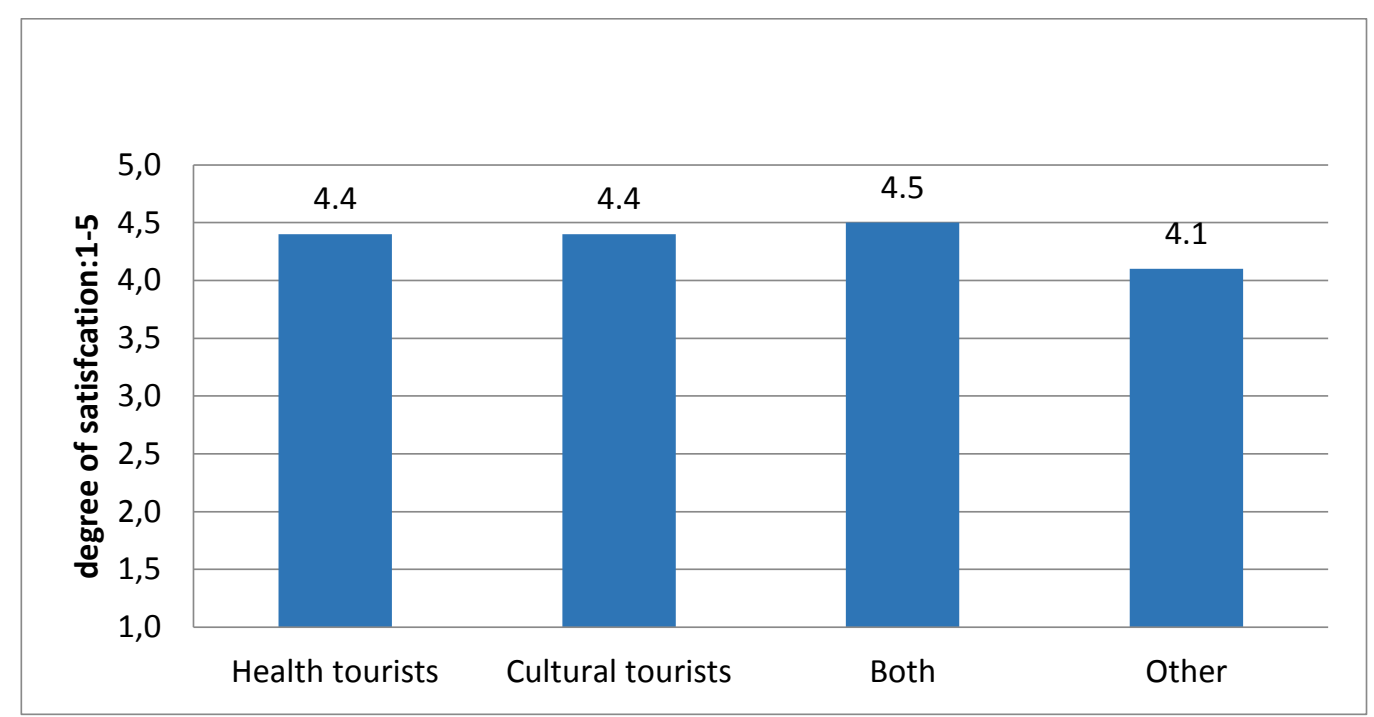

Source: Author.

Figure 9 shows how the respondents rated their satisfaction on a Likert scale from 1 to 5 . The result actually reveals no noteworthy difference between the groups. Participants with dual purposes had similar levels of satisfaction to those with a single purpose of visit. While it cannot be said that cultural pursuits heighten experiences, what it clearly demonstrates is that engaging in cultural pursuits can be as enjoyable as taking a health holiday. So it is not "either or", but both that are worth developing. For those destinations where spas are not enough for tourism to thrive, culture might be the safest bet. Even if cultural pursuits do not enhance tourists' experiences yet, from the economic perspective visitors' growing interest in local culture will certainly benefit the local community and help with the preservation of customs and traditions. 


\section{Conclusions and Recommendations}

This study aimed to contribute to the literature on slow tourism from a folklore perspective and set out to discuss the potentials of a Hungarian town - Mezőkövesd, situated at the heart of the Matyó land - as a slow destination, since it possesses some crucial slow destination criteria, including good accessibility and unique tourism drawcards. Related research suggests that many small towns are ailing around the world and are experiencing difficulties in recapturing their energies in our modern globalised, urbanised world. In Hungary for example, Makó with its unique gastronomy and the organic architect Makovecz's built heritage, or Mohács with its intangible world heritage (the Busó carnival) are two towns which could use a cultural focus in their tourism promotion.

The plight of small towns has been at the centre of scholarly research for some time and they could also find useful principles and guidance by joining the Cittaslow movement. However, there is still little research into linking slow tourism to smaller urban places. Today, Mezókövesd is well placed to be Hungary's first authentic slow destination, yet it is lagging behind Hungarian health resorts. As a multidimensional destination, it could be booming if packaged properly, and I would argue that a good context for this might be slow tourism.

As for the exploratory research, the most promising finding was the large proportion of returning visitors, which proves that visitors' loyalty is already there, and around which a successful marketing strategy could be put together. Returning visitors are an important source of promotion for tourism destinations, since they act as authentic narrators and ambassadors on behalf of the place. They are also more beneficial for the carrying capacity than first-time visitors because they are more likely to get off the beaten track, spread out spatially, and consequently make the destination less vulnerable and more sustainable. Therefore, there is a compelling argument for diversifying tourism offerings and designing a loyalty scheme.

The town is easily accessible by a variety of modes of transport including slower options. In fact, a sizeable proportion of respondents chose the latter, environmentally friendlier alternatives. Unfortunately, those who opted for car travel continued driving 
during their holiday. To limit car use outside and within the destination, more promotion of slower travel alternatives is needed; particularly the push for the mixed use of train and bicycle. The town is within easy reach of regional and national centres by rail, and bicycles are transported free of charge on most trains. The town itself possesses a network of cycling roads that locals frequently use, so the facility exists to literally take more mileage out of it. The only downside is the less appealing road connecting downtown with the health resort, where some landscape design of easy maintenance would not only fix the problem, but also would make sensory improvements for recreational cyclists to enjoy.

The survey also found that cultural purpose was the main motivating factor to embark on a trip to the town, since more people selected cultural reasons than health or other motivations, providing a solid foundation for folklore-driven slow tourism. The 3.5 cultural sights per capita is an encouraging start, but the challenge in that respect is to make Matyó culture more enticing for health tourists. Respondents with dual motives (spa visit and culture) showed similar satisfaction levels to those with a single motive, which suggests that culture might be as attractive for visitors as spas. Folklore tourism is more labour-intensive than health tourism (spa and wellness) while the latter is more asset-focused; therefore, from the perspective of job creation, there is a compelling argument not to neglect cultural tourism.

As for the limitations of this research, unfortunately tourism development is not a panacea and there are a great number of settlements which do not stand out in any way. My concern was places with internationally recognized folklore where the 'slow' potential is there and yet the community has been underperforming. Former industrial towns and dormitory towns to name a few need a different recipe for success.

Hopefully, this exploratory research will serve as a catalyst for future academic discourse along the line of slow and folklore fusion, helping intriguing but struggling country communities to survive and prosper both domestically and globally. 


\section{References}

Adigüzel, D. \& Erikci, S.N. (2013). Local identity in slow city movement: A case-study in Taraklı. In E. Morello \& B.E.A. Piga (Eds.), Conference proceedings envisioning architecture: Design, evaluation, communication - EAEA11 2013 (p. 117). Roma: Edizioni Nuova Cultura. Retrieved from: http://www.labsimurb.polimi.it/11EAEA/T01/poster/EAEA11_POSTER_T01_ADIGUZEL.pdf American Folklore Society (s.d.). What is folklore? Retrieved from http://www.afsnet.org/?page=WhatlsFolklore

Baker, B. (2007). Destination branding for small cities: The essentials for successful place branding. Portland: Creative Leap Books.

Caffyn, A. (2012). Advocating and implementing slow tourism. In T.V. Singh (Ed.), Critical debates in tourism (pp. 373-379). Bristol: Channel View.

Cittaslow International Network (2014). About Cittaslow organization. Retrieved from www.cittaslow.org/section/association

Dickinson, J.E. \& Lumsdon, L.M. (2010). Slow travel and tourism. London: Earthscan.

Dickinson, J.E., Robbins, D. \& Lumsdon, L.M. (2010). Holiday travel discourses and climate change. Journal of Transport Geography, 18 (3), 482-489. doi:10.1016/j.jtrangeo.2010.01.006

Dure, B. (2014, 1 outubro). Why millennials are avoiding small-town America. Retrieved from http://www.ozy.com/fast-forward/why-millennials-are-avoiding-small-townamerica/34058

European Council for the Village and Small Town (2010). Ecovast - After 30 Years (A report on the latest 10 years). Retrieved from http://www.ecovast.org/papers/ECOVAST\%20REPORT\%2010\%20years.pdf

European Union - European Regional Development Fund (2013). Urban vision central Europe small town 2020: QUALIST - Improving quality of life in small town. Retrieved from http://www.central2013.eu/fileadmin/user_upload/Downloads/outputlib/QUALIST_Trans national_Action_Plan_CE_SMALL_TOWN_2020.pdf

Fullagar, S., Markwell, K. \& Wilson, E. (Eds.) (2012). Slow tourism: Experiences and mobilities. Bristol: Chanel View Publications.

Honoré, C. (2005). In praise of slowness: Challenging the cult of speed. New York: HarperCollins.

Hungarian Central Statistical Office (2015). Data on Mezökövesd. Retrieved from http://www.ksh.hu/

Jamieson, W. (1993). Planning for small town cultural tourism. In Canadian National Committee of the International Council on Monuments and Sites - ICOMOS (Ed.), ISC Cultural Tourism 1993 - International Scientific Symposium (10 th General Assembly Sri Lanka) (pp. 90-96). Charenton-le-Pont: ICOMOS. Retrieved from http://www.icomos.org/publications/93sy_tou11.pdf

Korkmaz, H., Mercan, O. \& Atay, L. (2014). The role of Cittaslow in destination branding: The Case of Seferihisar. Current Issues of Tourism Research, 4 (1), 5-10.

Lambe, W. (2008). Small towns, big ideas: Case studies in small town community economic development. North Carolina, Chapel Hill: University of North Carolina.

Lumsdon, L.M. \& McGrath, P. (2011). Developing a conceptual framework for slow travel: A grounded theory approach. Journal of Sustainable Tourism, 19 (3), 265-279. doi: 10.1080/09669582.2010.519438

Mallik, A., Chaudhury, S. \& Ghosh, G. (2011). Nrityakosha: Preserving the intangible heritage of Indian classical dance. ACM Journal on Computing and Cultural Heritage, 4 (3). doi: $10.1145 / 2069276.2069280$ 
Mayer, H. \& Knox, P.L. (2006). Slow cities: Sustainable places in a fast world. Journal of Urban Affairs, 28 (4), 321-334. doi: 10.1111/j.1467-9906.2006.00298.x

Mezőkövesd (2014). Seasonal tourist information. Mezőkövesd: Tourinform Hungarian National Tourist Office. Available at http://mezokovesd.hu/userfiles/file/latnivalok/mk_2015.pdf

Murayama, M. \& Parker, G. (2012). 'Fast Japan, slow Japan': Shifting to slow tourism as a rural regeneration tool in Japan. In S. Fullagar, K. Markwell \& E. Wilson (Eds.), Slow tourism: Experiences and mobilities (pp. 170-184). Bristol: Channel View Publications.

Noyes, D. (2004). Folklore. In A. Kuper \& J. Kuper (Eds.), The social science encyclopedia (3 $3^{\text {rd }}$ ed.) (pp. 375-378). New York: Routledge.

Oxford Dictionaries (2014). Definition of folklore in English. Retrieved from http://www.oxforddictionaries.com/definition/english/folklore

Parkins, W. (2004). Out of time: Fast subjects and slow living. Time \& Society, 13 (2-3), 363382. doi: 10.1177/0961463X04045662

Petrini, C. (2007). Slow food nation: Why our food should be good, clean, and fair (Trad. J. Hunt). New York: Rizzoli Ex Libris.

PIRISI, G. (2008). A magyar kisvárosok differenciált fejlödése a rendszerváltozás után [After the regime change: The differential development of Hungarian small towns]. Thesis dissertation. Retrieved from http://old.foldrajz.ttk.pte.hu/phd/phdkoord/nv/disszert/disszertacio_pirisi_nv.pdf

Rátz, T. (2010). Meleg vizű források Japán belföldi és nemzetközi turizmusában (Hot springs in Japanese domestic and international tourism). In M. Smith \& L. Puczkó (Eds.), Egészségturizmus: gyógyászat, wellness, holisztika (Health and Wellness Tourism). Budapest: Akadémiai Kiadó.

Slow Budapest (2015). Retrieved from http://slowbudapest.com/

Slow Food (2015). Slow food philosophy. Retrieved from http://www.slowfood.com/ournetwork/network-of-members/

Sugiyama, M., \& Nobuoka, S. (2007). Slow Food kara Slow Tourism he (From slow food to slow tourism). Tokai Women's Junior College. Kiyou, 33, 1-8.

Tietz, B. \& Rothhaar, P. (1991). City-Studie. Landesberg am Lech: Mi-Wirtschaftsbuch.

Uchida, K. (2006). Slow tourism no yukue yukue (Future direction of slow tourism). In Ryokō Sakka no Kai (Ed.), Slow tourism no tenbō yukue (Perspectives on Slow Tourism) (pp. 611). Tokyo: Gendai Ryoko Kenkyujo.

United Nations Educational, Scientific and Cultural Organization (2003). Convention for the safeguarding of the intangible cultural heritage 2003. Paris: UNESCO. Available at http://portal.unesco.org/en/ev.php-

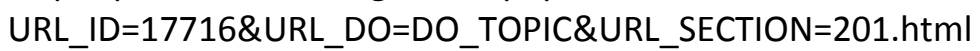

United Nations Educational, Scientific and Cultural Organization $(2009,2011,2012)$. Elements

on the Lists of Intangible Cultural Heritage: Hungary. Available at

http://www.unesco.org/culture/ich/en/state/hungary-HU?info=elements-on-the-lists

United States Census Bureau (2015). Metropolitan and Micropolitan Statistical Areas Main.

Retrieved from http://www.census.gov/population/metro/

Wilson, W.A. (1988). The deeper necessity: Folklore and the humanities. The Journal of

American Folklore, 101 (400), 156-167. doi: 10.2307/540106

BRIGITTA PECSEK is an interdisciplinary economist who has a wide range of interests in regional, cultural and alternative tourism. She is completing her doctoral thesis on slow tourism in the context of urban places at the Enyedi György Doctoral School of Regional Sciences, Szent Istvan University, Hungary. Her research interest focuses on the dichotomy of fast and slow in the field of tourism as well as on the link between slowness and different types of tourism such as cultural and religious tourism. She has also undertaken comparative research on Hungary and Japan. She 
holds a Master's Degree in International Relations from Budapest University of Economic Sciences and Public Administration, and studied linguistics and French at Macquarie University, Australia. She teaches tourism-related subjects at Kodolányi János University of Applied Sciences in Budapest. Institutional address: Szent István University, Enyedi György Doctoral School of Regional Sciences, 2100 Gödöll, Páter Károly utca 1, Hungary.

Submitted: 1 November 2015.

Accepted: 8 March 2016. 